\title{
Tourism Evolution in Region 2 SE
}

\section{Daniela Lavinia BALASAN ${ }^{\star}$, Florin Marian BUHOCIU ${ }^{\star \star}$}

\begin{tabular}{l}
\hline \multicolumn{1}{c}{ A R T I C L E I N F O } \\
\hline Article history: \\
Accepted March 2020 \\
Available online May 2020 \\
\hline JEL Classification \\
L23, Z32 \\
Keywords: \\
Development, Tourism potential, \\
Indicators, Project, Capacity \\
\hline
\end{tabular}

\begin{abstract}
A B S T R A C T
The tourist field is among the phenomena that have managed to impose itself in the contemporary era, and its spectacular development is characteristic of our century, especially today. The modern man is increasingly concerned about leisure, wanting to escape from the city's artificial environment to a peaceful and relaxing setting that nature offers. Tourism is becoming a necessity for the modern man.
\end{abstract}

(C) 2020 EAI. All rights reserved.

\section{Introduction}

In the South East region, we encounter almost all forms of relief, namely: Barăgan's Plain; Danube Meadow; Black Sea coast; Măcin mountains together with the Dobrogea Plateau; Part of the Curvature Carpathians. The potential is very high in this area due to the richness of natural resources. We encounter natural lakes that have therapeutic properties, the Danube Delta, the Small Island of Braila, but not least the Black Sea coastline which owns $70 \mathrm{~km}$ of coastline.

\section{General notions of tourism}

"Too rich to be framed in a definition, the sphere of tourism has at its heart Homo viator, i.e. the man who travels in time and space, trying to conquer them, knowing them. Conquering the surrounding space through the headset paved the way for knowledge, the journey becoming a way of being, a condition in communicating and understanding a system of interconnecting vessels between systems of different values."

a. Definitions

Tourism can be defined as an important component of the economy. It is considered „a form of recreation, along with other leisure activities”. Tourism involves „people's temporary movement to destinations outside their usual residence and activities during their time at those destinations".

Through tourism we mean the following:

- All activities spent by man in his spare time by making trips to the country or abroad in order to accumulate general knowledge, rest, treatment or entertainment or sports;

- Branch of the industry carried out in order to satisfy all the goods and services that the tourist requests.

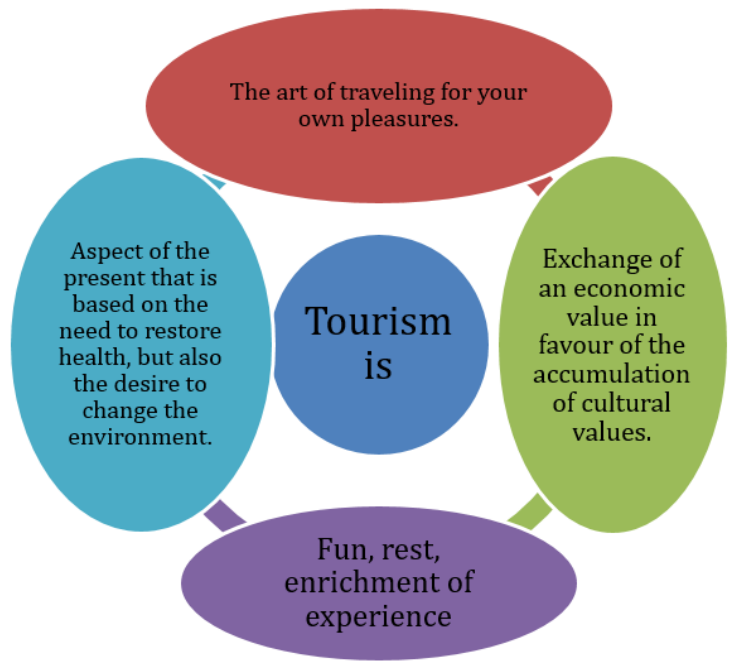

${ }^{\star,, \star \star}$ Dunarea de Jos University of Galati, Romania. E-mail addresses florin.buhociu@ugal.ro (F. M. Buhociu - Corresponding author) 


\section{b. Tourism functions}

We highlight five functions of tourism, namely:

The economic function, which is the most important function of tourism because the tourism economy leads to an increase in the level of economic systematization of areas with tourist possibility, as a result of the achievement of national income. This function stimulates the branches of industry, transport, agriculture and trade.

The social function involves the restoration of the workforce, thus influencing all economic branches, by increasing the cultural degree of society, in drawing up a modern lifestyle. With the help of these functions, tourism involves stable and efficient use of the regional workforce, reducing commuting or emigration.

The political function involves the rapprochement between peoples and is an element of peace and sorting. In conflicting areas tourism decreases in intensity or even does not appear at all.

The educational function is very important because it implies the possibility of understanding nature, society, art and reality.

The function of relaxation and leisure involves therapeutic factors such as sun, air, forests, thermal waters.

Although, Romania has a wide range of tourist attractions, it is not among the most visited countries, but not the last visited, as we can see in the figure below.

Figure No 1. Tourism positioning of Romania (millions)

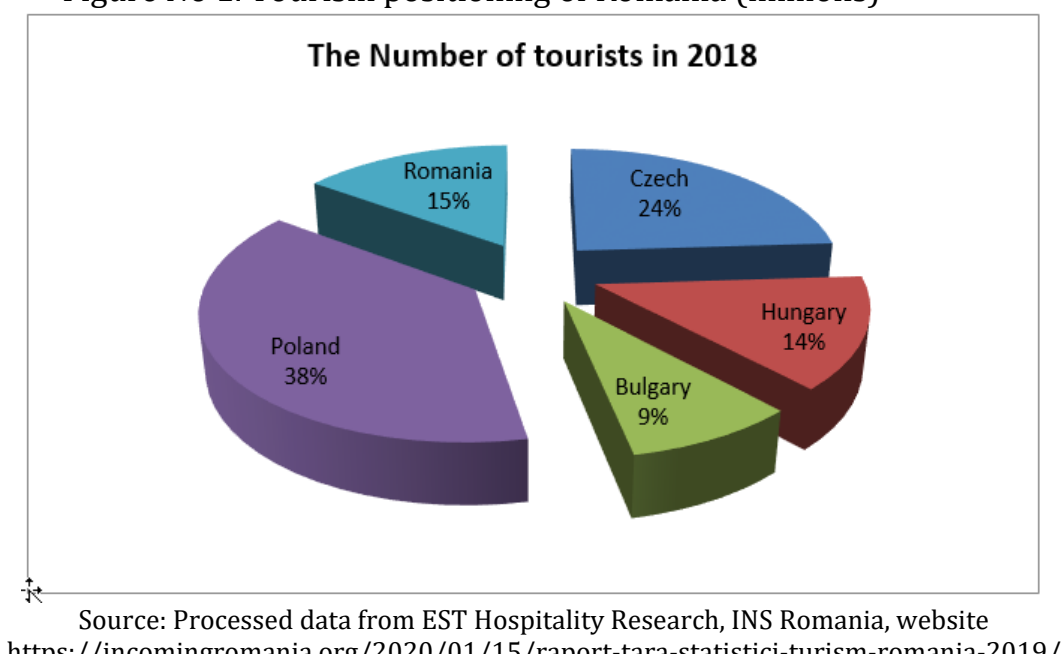

\section{Tourism potential of South East Region}

The tourist potential represents „all attractions belonging to the natural or anthropogenic framework, harnessed through tourist facilities and generating flows with areas of domestic and international origin moving destination areas where tourist products are consumed in a touristic manner, resulting from a potential and its arrangement".

c. Geographical classification

Map 1. Geographical location of the ragions from Romania

Source: image retrieved from https://portalsm.ro/2019/03/regiunea-din-nord-vest-pib-pe-cap-de-locuitor-la-jumatate-din-mediaeuropeana/ site on 17.01.2020 
The South-East region is located in the southeastern part of our country and borders Bulgaria in the south, in the East by the Republic of Moldova, Ukraine and the Black Sea, in the north by the North-East Region, and in the west and south by the Muntenia region and the Centre Region.

This region is the only one that can enjoy opening to the sea, which contributes to the development of maritime tourism. The location is great, the staff is very friendly and helpful. The region includes The Port of Constanta, Mangalia, Brăila, Galaţi, Tulcea and Sulina.

Region 2 South East consists of 6 counties, namely Buzău, Brăila, Galaţi, Vrancea, Tulcea and Constanța, being represented by county councils, local, municipal, city and municipal councils. Here are included 11 municipalities, 24 towns, 355 municipalities and 1447 villages.

\section{d. Description}

The South-East region ranks first in our country on the preservation of biodiversity, which has the largest area of protected areas in the whole country.

In this region, tourism determined by the presence of characteristic resources, such as the Black Sea coast and the Danube Delta, spa resorts, hostels, as well as monasteries, archaeological sites and memorial houses. The tourist landscape offered by the Black Sea is rarely found, with a specific uniqueness. Tourists can enjoy sub-water and water sports, as the water has a small salinity.

Our country's seaside consists of 13 resorts that have tourist, leisure and treatment accommodation institutions, and attract impressive streams of tourists.

The Danube Delta is the second largest in Europe (after that of the Volga River), and is a special attraction with great scientific value and high tourist potential, especially after its inclusion in 1990, along with other adjacent natural areas, in the Danube Delta Biosphere Reserve.

Here we meet a multitude of nature reserves, such as muddy Volcanoes in Buzău County. The most important natural lakes in our country are found over $90 \%$ in the South-East Region, although they have not been very landscaped or promoted today.

The natural resources of the South-East region are very rich; they also include protected areas. We see in the table below the situation of protected areas in the region and their location.

Table No. 1. Description of National, Natural Parks and Biosphere Reserve within the South-East Region

\begin{tabular}{|c|c|c|}
\hline Name & Description & Geographical location \\
\hline $\begin{array}{l}\text { Biosphere Reserves } \\
\text { in the Danube Delta }\end{array}$ & $\begin{array}{l}\text { The Danube Delta is different, both by surface } \\
\text { and by the level of biological diversity. It has } \\
\text { triple international status: Danube Delta } \\
\text { Biosphere Reserve, Ramsar Site, National and } \\
\text { Cultural World Heritage Site. }\end{array}$ & $\begin{array}{l}\text { The park stretches in Tulcea and } \\
\text { Constanța counties, in the north- } \\
\text { east of the region. }\end{array}$ \\
\hline $\begin{array}{l}\text { Balta Mică Natural } \\
\text { Park of Braila }\end{array}$ & $\begin{array}{l}\text { This park has an area of } 17,529 \text { hectares and } \\
\text { comprises forests of natural eutrophian swarms } \\
\text { and lakes, typha swamps, bushes, meadow wet } \\
\text { meadows, septic meadows. }\end{array}$ & $\begin{array}{l}\text { The park is located in Brăila } \\
\text { County, specifically in the } \\
\text { floodmeadow of the Danube. }\end{array}$ \\
\hline $\begin{array}{l}\text { Măcinului } \\
\text { Mountains National } \\
\text { Park }\end{array}$ & $\begin{array}{c}\text { The park has an area of } 11,321 \text { ha and is divided } \\
\text { in two, namely The Pricopan Ridge and the } \\
\text { Măcinmountains, which are the oldest mountains } \\
\text { in our country. }\end{array}$ & $\begin{array}{l}\text { Parcuş is located in Tulcea } \\
\text { County. }\end{array}$ \\
\hline $\begin{array}{l}\text { Lower Prut Low } \\
\text { Meadow Natural } \\
\text { Park }\end{array}$ & $\begin{array}{l}\text { It has an area of } 8,247 \text { ha and includes } 4 \text { nature } \\
\text { reserves and special protection areas. }\end{array}$ & $\begin{array}{l}\text { It is located in the eastern part of } \\
\text { Galaţi County. }\end{array}$ \\
\hline $\begin{array}{l}\text { Putna-Vrancea } \\
\text { Nature Park }\end{array}$ & $\begin{array}{l}\text { The park area is 38,204 ha and enters the } \\
\text { external group of the Curvature Carpathians. }\end{array}$ & $\begin{array}{l}\text { It is located entirely in Vrancea } \\
\text { County. }\end{array}$ \\
\hline
\end{tabular}

The natural heritage of the region is impressive and regional routes can be possible, such as visiting vineyards in Vrancea, Tulcea, Constanta and Buzău, a danube river cruise, as well as on the Black Sea.

In the map below we can see in more detail the tourist activities of this area. 


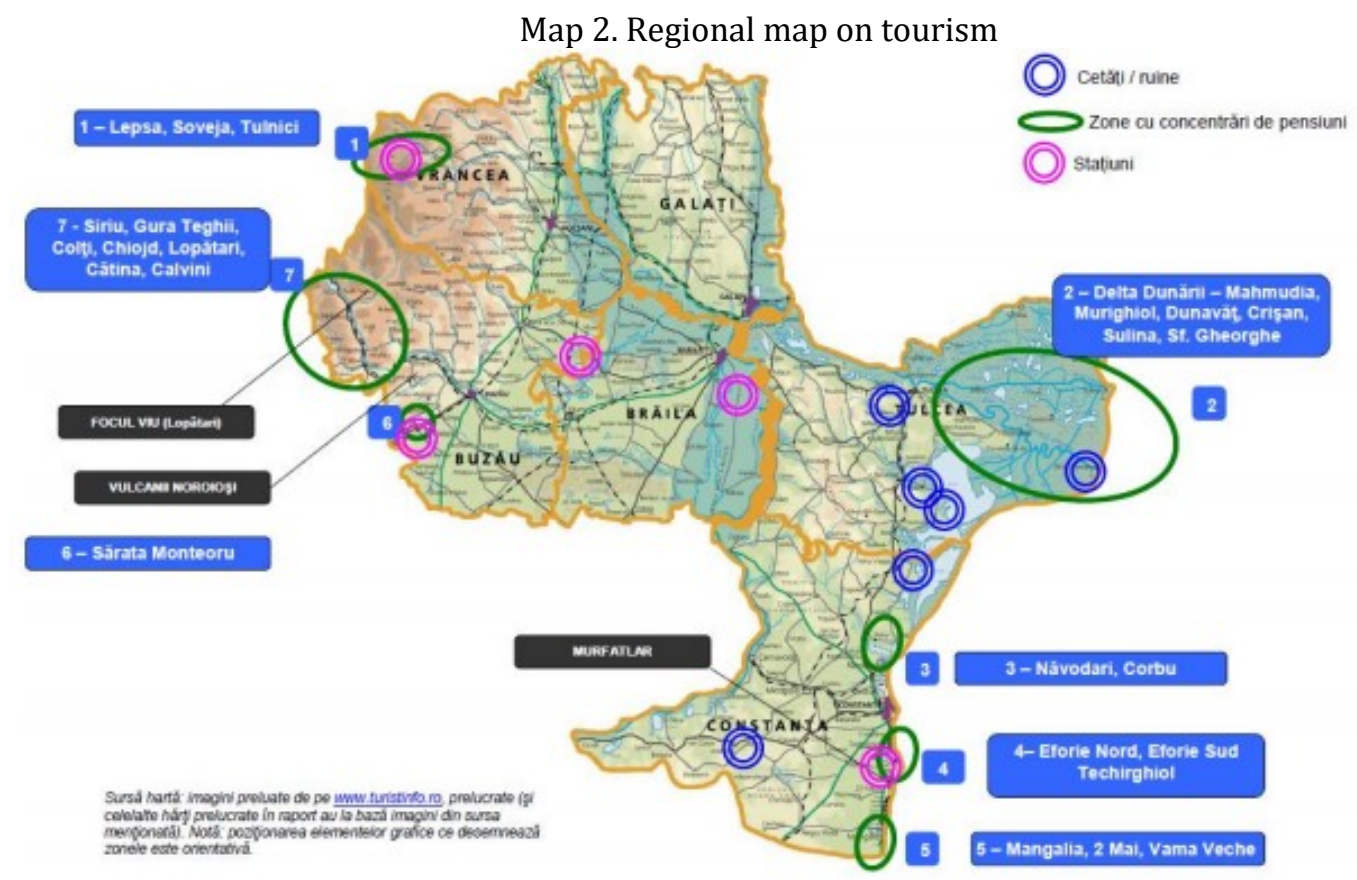

Source: Image retrieved from the website www.turistinfo.ro; Study edited by the National Foundation of Young Managers within the project "Entrepreneurs in Tourism", 2007-2013

\section{Evolution of Galaţi on Tourism}

Galați County enjoys a privileged position in our country. It borders to the north by Vaslui County, to the south by Brăila County, to the east by the Danube and Prut, and to the northwest by Vrancea County. The Danube and Prut are natural boundaries separating the county from Tulcea and The Republic of Moldova. Below we see a map of the protected areas of Galaţi County.

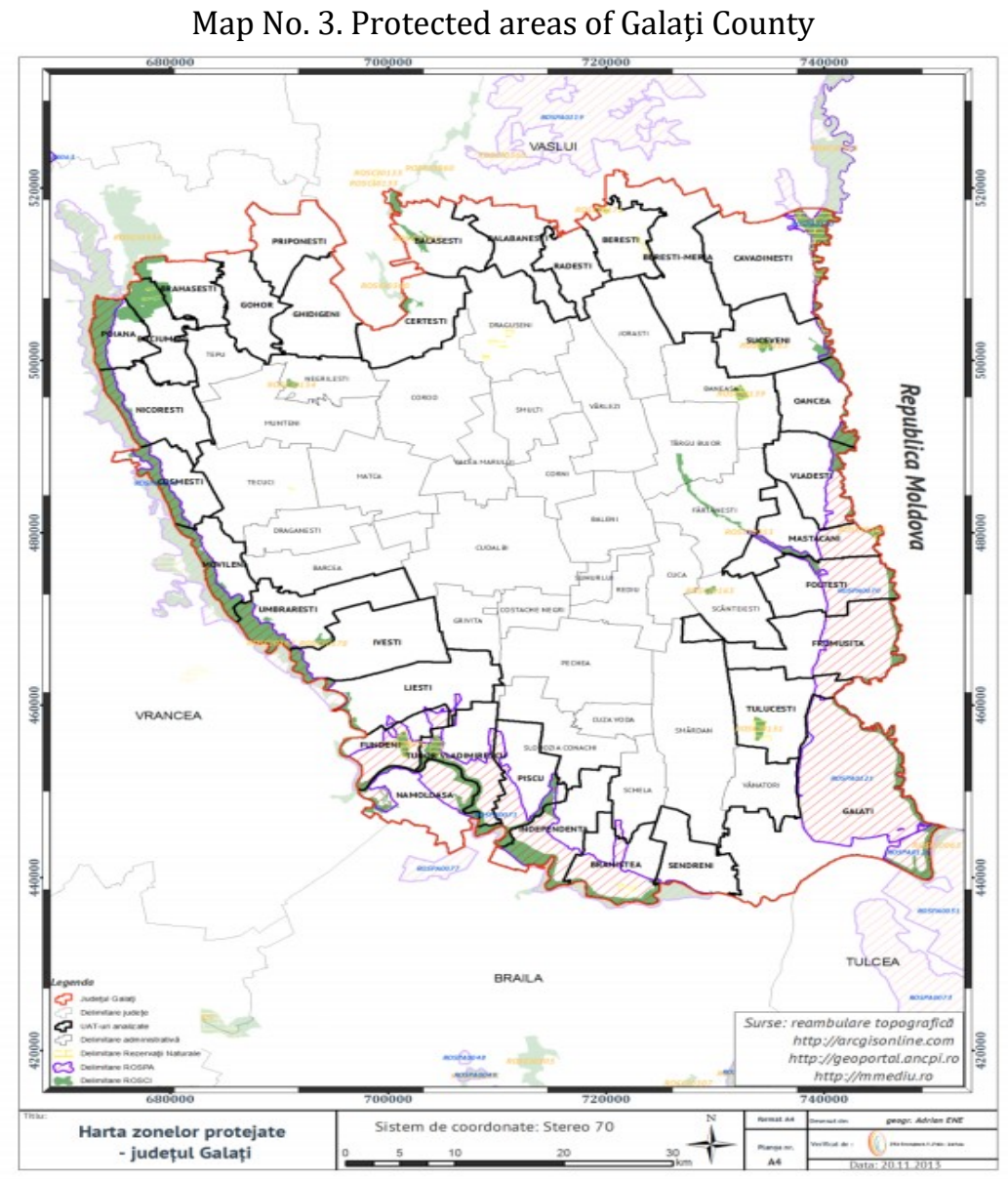

Source: image retrieved fromhttps://www.cjgalati.ro/images/stories/formulare/potential-turistic.pdf site on January 31, 2020 
In Galaţi County we find 11 Sites of community importance, 4 sites of special importance, a Natural Park and 14 nature reserves. The development of tourism in this area could lead to economic growth and the improvement of traditional crops.

The exercise of uncontrolled tourism leads to degradation of the natural environment. Because of these major transformations made by man, soil and flora suffer. Environmental pollution has occurred at the same time as the use of cars in all human actvities, but also to enter tourist destinations. They lead to air pollution through the large amount of denouees released into the atmosphere, but also by the fact that tourists do not follow specially designed routes and use alternative roads.

Access by means of transport auto, both on public roads and their parking on the vegetable space, will lead to the degradation of habitats characteristic of forest or plain areas.

In Galaţi we meet 263 protected historical monuments, and almost 43 of them are classified in category A and have national value.

Sights of Galati: Public garden; Mihai Eminescu Park; Archaeological site of Barboşi; Archdiocese of the "Lower Danube"; Tălăşmani Forest in Bereşti; Gârboavele Forest Zoo; "Dunărea de Jos" University of Galați; Danube Waterfront.

\section{Indicators on tourist potential in Galaţi County}

The data in July of the previous year were higher than in 2018. Both the number of tourists in our country and that of foreign tourists has increased.

Figure No 2. Tourists arrived in Galati

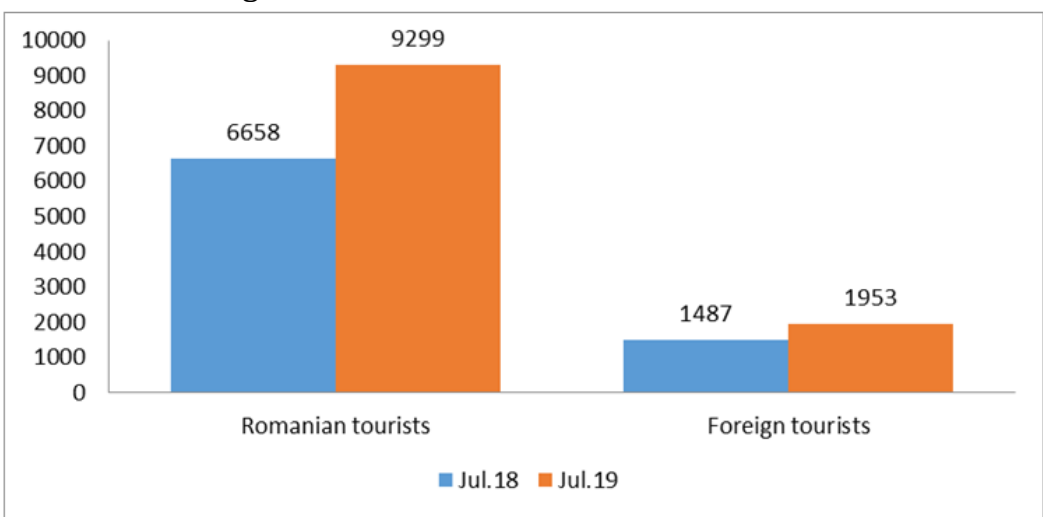

Source: Properly processed data from https://www.galati.insse.ro/comunicate-de-presa/turismul-in-judetul-galati-luna-iulie2019/ website

\section{Conclusions}

In order to achieve a very responsible tourism practice, concentrated measures are needed to clarify the limiting factors found. The tourism development in recent years in the South East region 2 is also due to the Romanian coastline, which registers progressive increases in the summer season.

Even if our country is predominantly agricultural and enjoys a vast cultural and natural patrimony, rural tourism is not in a state of development, although this would lead to improved activities leading to income for rural areas.

Due to the lack of methods of promoting poorly developed tourism and marketing, tourism cannot develop, with investors failing to do their business in rural areas.

With the help of adequate marketing and various types of support, everything Romanian tourism offers could be harnessed in a diversified and attractive way, minimizing the negative impact on the environment, while generating jobs and additional revenues.

\section{References}

1. Bleahu A., Rural development in the European Union, January, 2005.

2. Buhociu F.M., Tertorial resources to support sustainable rural development in the European context, Europlus Publishing House, Galaţi, 2016

3. Dinu M., Tourism Geography, University Publishing House, Bucharest, 2005

4. Holloway J., The Business of Tourism, Editura Pitman Publishing, London, 1994

5. Lupaşc I., Lupaşc A., Andone I., "Using Intelligent Technologies For Improving Decisional Processes, Iaşi, 2010

6. Teiușanu I., Tourism Geography, Academy Publishing House, Bucharest, 2008

7. Witt St. F., The Management of International Tourism, Editura Unwin Hyman Ltd, Londra, 1991, pag.8

8. https://www.catchy.ro/regiunea-sud-est-din-romania-este-a-doua-cea-mai-saraca-din-ue/153246

9. http://infraed.ro/wp-content/uploads/2018/10/PRAI-SE-.pdf

10. https://www.piarom.ro/wp-content/uploads/2016/11/Studiu_forta_de_munca-2016.10.03-TIPAR.pdf?x44818 
11. https://www.academia.edu/19891249/ANALIZA_TURISMULUI_IN_REGIUNEA_SUD_MUNTENIA

12. https://incomingromania.org/2020/01/15/raport-tara-statistici-turism-romania-2019/

13. https://portalsm.ro/2019/03/regiunea-din-nord-vest-pib-pe-cap-de-locuitor-la-jumatate-din-media-europeana/

14. http://www.parcmacin.ro

15. http://www.adrse.ro/Regiunea/Turism_Patrimoniu.aspx

16. www.turistinfo.ro

17. https://www.cjgalati.ro/images/stories/formulare/potential-turistic.pdf

18. https://www.galati.insse.ro/comunicate-de-presa/turismul-in-judetul-galati-luna-iulie-2019/ 